DOI: $10.2478 / \mathrm{v} 10025-012-0014-\mathrm{z}$

JOURNAL OF WATER

AND LAND DEVELOPMENT

J. Water Land Dev. No. 15, 2011: 157-166

\title{
Application of SWAT model to small agricultural catchment in Poland
}

\author{
Jan BRZOZOWSKI ${ }^{1)}$, Zygmunt MIATKOWSKI ${ }^{2}$, Damian ŚLIWIŃSKI ${ }^{1)}$, \\ Karolina SMARZYN'SKA ${ }^{2}$, Maria ŚMIETANKA ${ }^{1)}$
}

\author{
${ }^{1)}$ Institute for Technology and Life Sciences, Research Division in Warsaw, ul. Rakowiecka 32, 02- \\ 532 Warsaw, Poland; e-mail: jan.brzozowski@gmail.com \\ ${ }^{2)}$ Institute for Technology and Life Sciences, Research Division in Bydgoszcz, ul. Glinki 60, 85-174 \\ Bydgoszcz, Poland; e-mail: itepbyd@itep.edu.pl
}

\begin{abstract}
Poland is obliged, like the other EU countries, to implement the Water Framework Directive - WFD (2000/60/WE) by the end of 2015. The main objective of WFD is to provide normative quality of all water resources. To reach this goal reduction of water polluter emission to the environment is needed. Our project focuses on pollution from agricultural sources which share in global pollution is high and growing still. As a pilot area, where the WFD is going to be implemented, small agricultural Zgłowiączka catchment was chosen.

The state monitoring of surface water quality for the catchment is conducted in three points along the Zgłowiaczka River. In each of these three points, nitrates concentration periodically significantly exceeds the allowable value of $50 \mathrm{mg} \mathrm{NO} \cdot \mathrm{dm}^{-3}$. The highest average monthly values of nitrates concentration in years 1990-2007 occur in February, March and April, which indicates on agriculture as a source of pollution. The Zgłowiaczka catchment is an area where reduction of nitrogen run-off from agricultural lands to water resources is especially needed. The main topic of the research carried out in the Polish-Norwegian project is to propose different means for reduction of migration of nitrate to surface water based on modeling approach. In the paper a conception of creating buffer zones using SWAT model is presented. We considered fitting the buffer zone width, depending on the flow rate of water flowing from the fields to the stream. Using SWAT model interface a map of potential flow under the conditions of the intensive precipitation was generated. The next step was distribution over the whole Zgłowiączka catchment, places with high density of the temporal streams network. It was done using GRASS program. The map of stream "density" was done by assigning the raster number which is the sum of raster in the neighbourhood (radius of neighbourhood smaller or equal 25 raster). The choice of the most endangered subbasins was done on base of visual evaluation of the surface flow density map.

It is visible in the results that filter strips on endangered areas are far more effective and therefore more required. If the width of the vegetated buffer strips is not sufficient, it will not attain the desired effectiveness. Conversely, if the width is too great, it will cause agricultural land waste, preventing farmers' interest in cooperating with environmental preservation efforts. For the above reasons, it is important to set a reasonable width range. According to the results we are suggesting wider buffer zones in endangered subbasins and narrow in other subbasins.
\end{abstract}

Key words: agriculture, nitrate, diffuse pollution, SWAT, buffer strips 


\section{INTRODUCTION}

The European Union Water Framework Directive (WFD) is one of the most significant legislative instruments in the water field in recent years (DWORAK et al., 2005). The main objective of WFD is to achieve good quality of all water resources in the Community by 2015 . To reach this goal reduction of water polluter emission to environment is needed, both from point and non-point sources. The control of nonpoint sources as compared to point sources is much more complex and difficult in that nonpoint sources involve complex transport and transformation through different media (DROLC et al., 2008).

In many regions intensive agriculture is a major source of emission of diffuse pollution to surface waters and groundwaters (KYLLMAR et al., 2005). Compared to point sources, where treatment is the most effective method of pollution reduction, abatement of diffuse pollution focuses on a set of different actions such as: land use, good agricultural practices and surface water management. That is the reason, why the implementation as well as reach of the WFD goals on the intensively agricultural used areas is a very complex and long-lasting task, in which administration responsible for implementation of WFD, as well as farmers and scientists, should be involved.

Our project is focused on supporting administration and self-governmental organization in the implementation of effective strategies in catchment management, based on modelling approach, to reach the good quality of surface water. The strength of using models in scenario analyses is their capability of formalising complex decision making through quantifying the consequences of a large number of policy options in a consistent manner (WOLF et al., 2005) The modelling approach is helpful in the actual water quality assessment and enables early warning against excessive pollution load. We choose a SWAT model, which is developed to predict the impact of land management practices on water, sediment and agricultural chemical yields in watershed with varying soils, land use and management conditions over long periods of time (NEITSH et al., 2002).

The aim of this paper is to describe the state of advance in application of SWAT model to intensively agricultural used pilot catchment and its use for catchment management.

\section{MATERIALS AND METHODS}

\section{STUDY AREA}

The upper Zgłowiączka River catchment $\left(129.6 \mathrm{~km}^{2}\right)$ is situated in central Poland. The area of the catchment has a very poor hydrografic network, which is formed only by open ditches and subsurface drainage system. Drainage system ac- 
celerates circulation of water and nutrients in the catchment (around $70 \%$ of the whole catchment is drained).

The Zgłowiączka River is a left tributary of Vistula River. The investigations were carried out in the upper part of the river, above the Głuszyńskie Lake.

The catchment is an area with a very high quality of agricultural production space. The dominant soil type is mainly high agricultural quality Phaeozems and Luvisols developed from sandy loams and loams underlain by low permeable loams. On this area arable land is a dominant form of land use (90\%), grasslands occur only in small local land depressions and in the river valley (3.9\%). The landscape of the catchment is flat and typical for intensive agriculture: poor, open and without any midfield trees and forest complexes. There are no buffer zones along the river, fields adjoin directly to the river bed and ditches.

The yearly sum of precipitation in the catchment region is the lowest in Poland. The average yearly sum of precipitation is $500 \mathrm{~mm}$ (600 $\mathrm{mm}$ for Poland), during the vegetation period - about $300 \mathrm{~mm}$. The water balance of filed crops in average year is negative. Potential evapotranspiration in Zgłowiączka catchment is $650 \mathrm{~mm}$ per year and in the vegetation period between $450-500 \mathrm{~mm}$ (ZŁONKIEWICZ et al., 2007). The water deficit for arable crops is a main factor limiting agriculture production and efficiency of fertilizer use. The excess of precipitation related to potential evapotranspiration occurs during winter time. The subsurface drainage system combined with the open ditch systems protects soils against waterlooging.

In the catchment area water needs and water balance for main crops are known. However there is lack of water balance analyses in the scale of the catchment taking into consideration spatial crop structure and fertilization level which change depending on economic conditions.

In 2004 almost the whole catchment was designated as Nitrate Vulnerable Zone (NVZ) according to Nitrate Directive of European Union (91/676/EEC). The NVZs in the European Union Member States were designated on the basis of state monitoring results that indicate that surface waters in these zones are affected by nitrate pollution from agriculture. In the Zgłowiączka catchment state monitoring is conducted in three points along the river. In one point before the Głuszyńskie Lake surface water samples have been taken since 1990. Additionally, since 2000, monitoring is conducted in two other points. Nitrates concentration periodically significantly exceeds allowable value of $50 \mathrm{mg} \mathrm{NO}{ }_{3} \cdot \mathrm{dm}^{-3}$ (Fig. 1).

On the basis of the equation 1 the nitrate nitrogen load $\left(\mathrm{kg} \cdot \mathrm{ha}^{-1}\right)$ from the catchment was calculated:

$$
L=\sum_{t=1}^{t=T}\left(\overline{Q_{t}} C_{t}^{I}\right)
$$




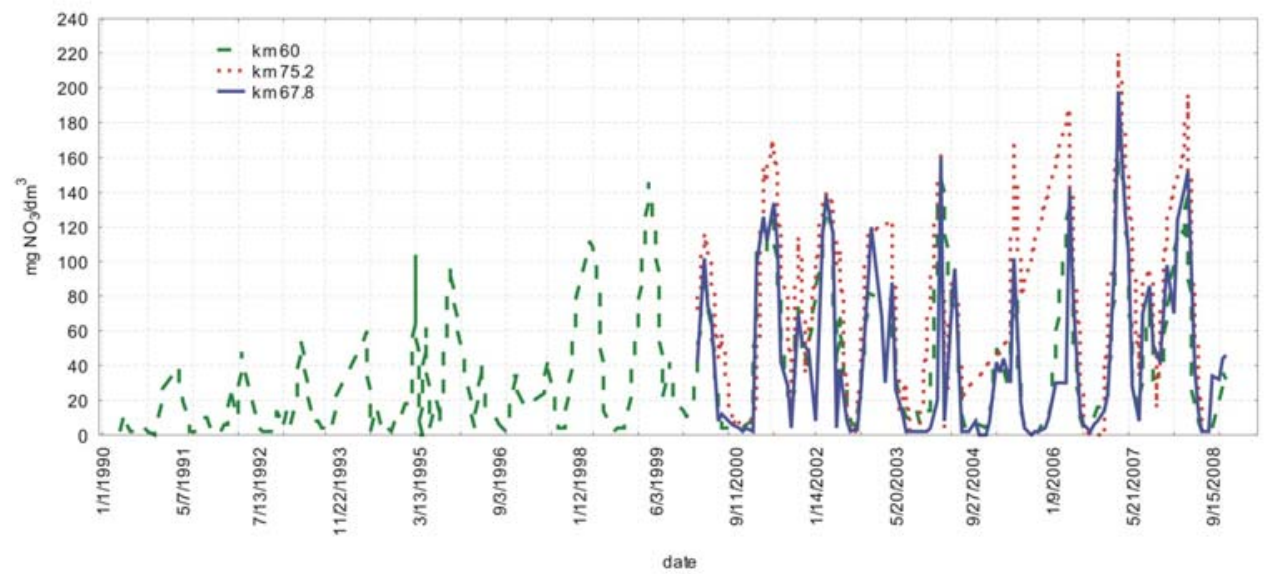

Fig. 1. Nitrates concentrations in upper Zgłowiączka River in 1990-2008

where:

$L \quad-\mathrm{N}_{-} \mathrm{NO}_{3}{ }^{-}$load outflowing from the catchment in a given time period $T$, for example 365 days;

$C_{t}^{I}$ - average $\mathrm{N}-\mathrm{NO}_{3}{ }^{-}$concentration value, for days between two subsequent analysis, the value was determined using linear interpolation;

$\overline{Q_{t}}$ - average daily outflow;

$t \quad-$ subsequence days.

The nitrate nitrogen load was calculated for year 2007, due to the luck of outflow data for other years. In contrast to periodical high nitrates concentration the yearly $\mathrm{N}_{-} \mathrm{NO}_{3}{ }^{-}$load amounts only $20 \mathrm{~kg} \cdot \mathrm{ha}^{-1}$. The explanation of that fact is low outflow coefficient, which in this year amounted 0.14 .

\section{MODEL DESCRIPTION}

Soil and Water Assessment Tool (SWAT) model is continuation of 30 years non-point source modelling (NEITSH et al., 2002). It is a physically based, time continuous simulation model that operates on a daily time step at catchment scale. It is designed to evaluate management practices on water quality and sediment production in large watersheds with varying of soils and land use over long periods of time. The watershed is divided into a number of subbasins where the smallest unit of discretisation HRU (Hydrological Response Units) is the result of overlay of the same of soil type, land use and slope.

The modelling processes such as: soil water content, surface runoff, nutrient cycle, crop growth and management practices are simulated for each HRU and then 
aggregated for the subbasin by weighted average (GRIZZETTI et al., 2003). SWAT simulates complete cycle of nitrogen and phosphorus taking into account nutrient mineralization, decomposition and immobilization. As nutrient inputs, SWAT takes into account natural sources as well as anthropogenic contribution, which includes both fertilizer applications (non-point sources) and waste water from treatment plants (point sources).

The model is widely used all over the world for modelling of diffuse emission of nutrients and water quality in rural areas (SHEPERD et al., 1999; CONAN et al., 2003; BOURAOUI et al., 2005; FENG et al., 2008) SWAT is also used as a tool, which can be helpful for evaluation of management actions for the implementation of WFD among the EU countries (BÄRLUND et al., 2007). The aim of our project was to create (using SWAT) of a tool for catchment management to support administration in implementation of the WFD in Poland.

\section{INPUT DATA}

SWAT is one of the hydrological models that requires very huge amount of data about topography (Digital Elevation Model), soil types, land use and meteorological condition. The problem is in availability of these data in Poland in proper resolution, special for small catchments.

For the project purposes we created a database with all data required for SWAT. This allows us to collected diffuse environmental data about the study area.

Digital elevation model was obtained from SRTM mission (radar satellite imagery) with pixel size of $90 \mathrm{~m}$. In this specific area of Zgłowiączka catchment, it was not enough for SWAT to determine the stream network, so the generation of it was supported by additional vector layer of the stream network generated from topographical map.

There was a problem with old soil data and, additionally, with polish soil classification not complementary with the US one. Therefore, basic pedological fields investigations and soil samples analysis were done to complete SWAT soil database.

The detailed information about crops planted in the research area is not available. It is possible to get the information on the community level, but only about selected farms, from the surveys made by local administration. So we assumed, that these farms represent enough the whole area. According to this information, the main crops in the research area are: winter wheat (about 37\% of area), spring barley, canola, corn, sugar beet and vegetables (mainly onion) - all about $12 \%$ of area. On the basis of satellite image from Landsat, the range of arable land was determined. The spatial resolution of $30 \mathrm{~m}$ allows distinguishing between settlements, forests and agricultural land. The next step was to divide arable land into polygons representing different crops, so that the area of polygons is similar to the data from 
the local administration. This was made on the basis of Landsat image too. A three band composition (two infrared bands and one red) was used for this purpose (MIATKOWSKI et al., 2006). The image is from the beginning of vegetation season (early May), so only parts of the fields are covered with vegetation. An assumption has been made that fields with vegetation are winter-wheat and canola fields. Others are without vegetation cover in this part of the year. According to this information, pixels covered with vegetation were divided into two groups: winter-wheat and canola, and other pixels into four groups: vegetables, spring barley, corn, and sugar beet. This method allows us to avoid totally random distribution of the crops.

SWAT requires daily values of meteorological parameters such as: precipitation, max and min temperature, wind speed, relative humidity and solar radiation. These data were colected from automatic meteorological station for eleven years (January 1997 - December 2007) by the Institute of Meteorology and Water Management (Division in Kraków). The data of precipitation, wind speed, temperature and relative humidity were used from one station, located in Kołuda. Solar radiation data were used from two other stations, Torun and Koło, which are located close to the research area. The default weather generator was replaced by user generator with values calculated for Kołuda, which of course better represents specific meteorological conditions of the research area.

\section{RESULTS}

The collected input data were loaded into the model. The whole watershed was divided into 23 subbasins. At the beginning we assumed the most simple classification of HRU - dominant soil type, land use and slope. Then some simulations had been done. The problem of proper calibration is in availability of specific data about flow and nitrate concentration. There are available hourly measurements of river water level from January to December 2007. On the basis of those values and some manual flow measurements the discharge curve was constructed. The daily discharge values calculated on the basis of discharge curve were loaded to SWAT - CUP (Calibration and Uncertainty Programs) and compared with the simulation discharge from SWAT. The NS coefficient for uncalibrated model for flow was between -0.44 and -0.62 depending on management practices. Also some manual comparison of the general parameters was done. The accuracy of the model was tested on the general water balance parameters and yields. The values and their annual changes are as expected. Manual approaches are still frequently used for calibration, although they are tedious, time consuming, and require experienced personnel (MULETA et al., 2005). The potential evapotranspiration (calculated using Penman-Monteith method) and water amount in soils is similar to measured. To collect data for precise calibration and validation of the model, investigative (considering hydrology and surface water chemistry) monitoring in the catchment is 
being organized. The preliminary results of that monitoring as well as results of SWAT simulations indicate, that the main nitrate leaching path from the catchment is subsurface drainage.

Although the SWAT model is still in calibration phase, some simple analysis of management options to reduce nutrient loads were done. One of the options analysed was a conception of buffer zones. Appropriate streamside vegetation and restriction of land cultivation will control nonpoint sources of pollution, enhance water resource utilization and help conservation (LIN et al., 2002).

Parts of the model interface for data preparation were used for determination surface outflow high risk areas and for visualization for the educational purposes mining of these buffer zones in reduction of nutrient loads leaching to surface waters. The next step was distribution over the all Zgłowiączka catchment places with high density of the temporal streams network. It was done using GRASS program. The vector lines of temporal streams were changed on raster format with resolution of $30 \mathrm{~m}$. The map of stream "density" was done by assigning the raster number which is the sum of raster in the neighbourhood (radius of neighbourhood smaller or equal 25 raster). Then sub-catchments were picked up (created by SWAT model) with the highest density of potential surface flow The choice of the most endangered sub catchments was done on base of visual evaluation of the surface flow density map.

The preliminary analysis, using SWAT, of filter strips effectiveness show that buffer zones on endangered areas are far more effective in protection of surface water quality against nitrate outflow. If the width of the vegetated buffer strips is not sufficient, it will not attain the desired effectiveness. Conversely, if the width is too great, it will cause agricultural land waste, preventing farmers' interest in cooperating with environmental preservation efforts. For the above reasons, it is important to set a reasonable width range (LIN et al., 2004). According to the results we are suggesting wider buffer zones in endangered subbasins and narrow in other subbasins (Fig. 2).

Implementation of buffer zones is effective measure of surface water protection and should be further developed. A good adjustment of plants to local conditions is as important as fast implementation. It will take few years until buffer zones reach full capacity in nutrients flow reduction. The work on shelter belts (anti erosion) will be continued and tested as additional measure of rivers protection. The change in rural landscape as well in biodiversity is very important added value. In further part of the project we are planning to analyze some problems of climate warming, as well adaptation strategies. The conception of creation of buffer zones using SWAT model can be used in other agricultural watersheds in the country. 


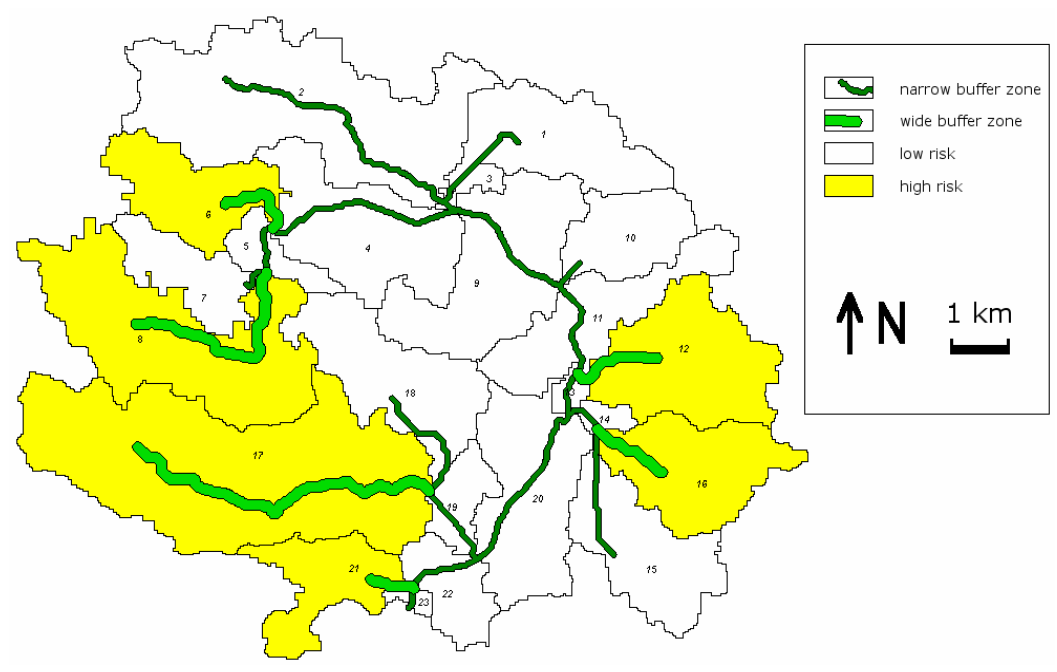

Fig. 2. Suggested buffer zones along the river and ditches in Zgłowiączka catchment

\section{CONCLUSIONS}

1. Water Framework Directive is one of the most difficult to fulfill from UE directives. The project focuses on creation of a tool, which can be helpful for local administration in the implementation of effective management strategies based on modelling approach. As it is shown above, SWAT model can be a very helpful tool for implementation of WFD even without very precise calibration and validation.

2. After verification, calibration and validation model is a useful tool in the time of dynamic economical and climatic changes. It gives the opportunity to tested some climatic changes and different management strategies to find the most effective and profitable solutions for protection of surface water quality on the intensively agricultural used areas.

3. In the frame of the project hydrological and chemical monitoring is organized. Data from these investigations will be used for more precise calibration and validation of the model.

4. Despite the fact, that the most of catchment area is flat, there is a local risk of nitrate surface outflow. Correctly designed buffer zones can significantly decrease the risk of nitrate outflow from the catchment area to the surface waters. The conception of creating buffer zones using SWAT can be implemented also in other catchments in Poland.

\section{ACKNOWLEDGEMENTS}

We would like to thank Norwegian Financial Mechanism for financial support of the project. Authors of the article are also very grateful for the great cooperation between institutes involved in the project and fantastic work of all team members. 


\section{REFERENCES}

1. BÄrlund I., KirkKala T., Malve O., KäMÄrI J., 2007. Assessing SWAT model performance in the evaluation of management actions for the implementation of the Water Framework Directive in a Finnish catchment. Environmental Modelling \& Software, 22, 5: 719-724.

2. Bouraoui F., Benabdallah S., Jrad A., Bidoglio G., 2005. Application of the SWAT model on the Medjerda river basin (Tunisia). Physics and Chemistry of Earth, 30: 497-507.

3. Conan C., Bouraoui F., Turpin N., De Marsily G., Bidoglio G., 2003. Modeling flow and nitrate fate at catchment scale in Brittany (France). Journal of Environmental Quality, 32, 6: 2026-2032.

4. Council Directive 91/676/EEC of 12 December 1991 concerning the protection of waters against pollution caused by nitrates from agricultural sources.

5. Drolc A., Koncan J.Z., 2008. Diffuse sources of nitrogen compounds in the Sava river basin, Slovenia. Desalination, 226, 1-3: 256-261.

6. Dworak T., Gonzalez C., LAaser C., InTERwies E., 2005. The need for new monitoring tools to implement the WFD. Environmental Science and Policy, 8, 3: 301-306.

7. European Parliament and the Council, 2000. Directive of the European Parliament and of the Council Concerning Establishing a Framework for Community Action in the Field of Water Policy (2000/60/EC), October 23, 2000.

8. FenG G., Ge Y., 2008. Numerical simulations of nutrient transport changes in Honghu Lake Basin, Jianghan Plain. Chinese Science Bulletin, 53, 15: 2353-3363.

9. Grizzetti, B., Bouraoui F., Granlund K., Rekolainen S., Bidoglio G., 2003. Modelling diffuse emission and retention of nutrients in the Vantaanjoki watershed (Finland) using the SWAT model. Ecological Modelling, 169, 1:25-38.

10. KYLLMAR K., LARSSON M.H., JOHNSSON H., 2005. Simulation of N leaching from a small agricultural catchment with the field scale model SOILNBD. Agriculture, Ecosystems and Environment, 107, 1: $37-49$.

11. LIN C.Y., CHOU W.C., LIN W.C., 2002. Modeling the width and placement of riparian vegetated buffer strips: a case study on the Chi-Jia-Wang Stream. Journal of Environmental Managements, 66: 269-280.

12. LiN Y., Lin C.Y., ChOUd W.C., Lin W. T., Tsai J.S., Wu C.F., 2004. Modeling of riparian vegetated buffer strip width and placement: A case study in Shei Pa National Park. Ecological Engineering, 23: 327-339.

13. Miatkowski Z., Lewiński S., Kowalik W., SoŁTYsik A., TuRbiak J., 2006. Przydatność zdjęć satelitarnych Landsat TM do identyfikacji intensywnie odwodnionych siedlisk hydrogenicznych w rejonie KWB Bełchatów. (Applicability of Landsat TM Satellite images to identification of intensively drained hydrogenics sites in the region of the brown coal mine Belchatów). Woda Środowisko Obszary Wiejskie. Rozprawy naukowe i monografie, 16: 1-80.

14. MulETA M.K., NiCKLOW J.W., 2005. Sensitivity and uncertainty analysis coupled with automatic calibration for a distributed watershed model. Journal of Hydrology, 306, 1-4: 127-145.

15. Neitsch S.L., ARnold J.G., KiniRy J.R., Williams J.R., King K.W., 2002. Soil and Water Assesment Tool Theoretical Documentation. Texas, Water Resources Institute, College Station, Texas.

16. ShePerd B., HARPER D., Millington A., 1999. Modelling catchment-scale nutrient transport to watercourses in the UK. Hydrobilogia 395/396: 227-237.

17. Wolf J., RÖTter R., Oenema O., 2005. Nutrient emission models in environmental policy evaluation at different scales - experience from the Netherlands. Agriculture, Ecosystems and Environment, 105: 291-306.

18. ZŁONKIEWICZ M., ŁABĘDZKi L., GrUSZKa J., 2007. Program nawodnień rolniczych w województwie kujawsko-pomorskim. (Agricultural irrigation program in kujawsko-pomorskie voivodship). Bydgoszcz, Gospodarstwo Pomocnicze przy K-PZMiUW. 


\section{STRESZCZENIE}

\section{Aplikacja modelu SWAT na terenie malej zlewni rolniczej w Polsce}

Słowa kluczowe: azotany, rolnictwo, strefy buforowe, SWAT, zanieczyszczenia rozproszone

Polska, podobnie jak pozostałe kraje członkowskie Unii Europejskiej, jest zobowiązana do wdrożenia Ramowej Dyrektywy Wodnej - RDW (2000/60/WE) do końca 2015 r. Głównym celem RDW jest osiagnięcie dobrego stanu ekologicznego wszystkich wód. Niezbędne jest więc ograniczenie emisji zanieczyszczeń zarówno do wód powierzchniowych jak i gruntowych. W polsko-norweskim projekcie pt. „Pilotażowe wdrożenie Ramowej Dyrektywy Wodnej i stworzenie narzędzia do zarządzania zlewnią" skupiono się na zanieczyszczeniach pochodzących ze źródeł rolniczych, których udział w ogólnym ładunku zanieczyszczeń jest bardzo znaczący i stale rośnie. W ramach projektu do wdrożenia RDW wybrano typowo rolniczą zlewnię górnej Zgłowiączki, zlokalizowaną na obszarze Kujaw.

$\mathrm{Na}$ terenie zlewni od 1990 r. prowadzony jest państwowy monitoring jakości wód powierzchniowych przy ujściu cieku do Jeziora Głuszyńskiego, a od $2000 \mathrm{r}$. w dwóch monitoring uzupełniono o dwa dodatkowe punkty pomiarowo-kontrolne na długości cieku. W każdym z tych punktów stężenie azotanów okresowo kilkakrotnie przekraczało dopuszczalną wartość $50 \mathrm{mg} \cdot \mathrm{dm}^{-3}$. Największe miesięczne wartości stężenia w latach 1990-2007 notowano w lutym, marcu i kwietniu, co wskazuje na pochodzenie zanieczyszczeń z rozproszonych źródeł rolniczych. W związku z tym obszar zlewni górnej Zgłowiączki to teren, na którym ograniczenie rozpraszania azotanów z rolnictwa do środowiska jest szczególnie potrzebne. Głównym celem projektu jest zaproponowanie działań prowadzących do ograniczenia rozpraszania azotanów do wód i przeanalizowanie ich skuteczności z wykorzystaniem modelowania. Do tego celu zastosowano hydrologiczny model SWAT, stworzony w celu przewidywania wpływu użytkowania terenu zlewni na jakość wód w długim czasie. W artykule przedstawiono koncepcję wykorzystania modelu SWAT do optymalnego określenia rozmieszczenia i szerokości stref buforowych na obszarze zlewni jako jednej z metod, prowadzących do ograniczenia procesu rozpraszania azotanów do wód. 